\title{
Origin and extension of the IFT complex in early eukaryotic evolution
}

\author{
J van Dam*, MC Field², M Huynen ${ }^{1}$ \\ From First International Cilia in Development and Disease Scientific Conference (2012) \\ London, UK. 16-18 May 2012
}

\section{Background}

The intraflagellar transport (IFT) complex is an ancient protein complex that facilitates active trafficking of proteins and molecules across the eukaryotic cilium. Based on similar domain compositions Avidor-Reiss et al. (2004) and Jékely et al. (2006) postulated that the IFT originates from an ancestral proto-coatomer complex that also gave rise to vesicle coating complexes (e.g. COPI, COPII, Clathrin) and the Nuclear Pore Complex. Using comparative genomics we provide direct phylogenetic evidence of the proto-coatomer origin of the IFT.

\section{Results}

We identified the COPI $\alpha,-\beta 2$ and $-\varepsilon$ subunits as closest paralogs to 12 IFT subunits comprising all three sub-complexes (IFT-A, -B and the BBSome). Our analysis suggests that IFT-A and the BBSome arose from an IFT-B like proto-IFT complex by intra-complex duplication of subunits. We show that the BBSome is a modular component that is lost in eukaryotic species as a precursor to ciliary loss in organisms such as fungi, apicomplexa and plants.

\section{Conclusions}

Identification of the proto-coatomer origin and subsequent evolution of the IFT complex strengthens the suspected involvement of IFT components in vesicle transport and provides a rationale for its mechanism. Expansion of ancestral subunits by duplication as well as co-evolution of specific subunits provides some insight on modularity and internal structure of the IFT complex.

\footnotetext{
Author details

'CMBI, NCMLS, Radboud University Medical Centre, the Netherlands.

${ }^{2}$ Department of Pathology, University of Cambridge, UK.
}

\footnotetext{
* Correspondence: teunis.jp.vandam@gmail.com

${ }^{1} \mathrm{CMBI}, \mathrm{NCMLS}$, Radboud University Medical Centre, the Netherlands

Full list of author information is available at the end of the article
}

Published: 16 November 2012

doi:10.1186/2046-2530-1-S1-P56

Cite this article as: van Dam et al:: Origin and extension of the IFT complex in early eukaryotic evolution. Cilia 2012 1(Suppl 1):P56.

\section{Submit your next manuscript to BioMed Central and take full advantage of: \\ - Convenient online submission \\ - Thorough peer review \\ - No space constraints or color figure charges \\ - Immediate publication on acceptance \\ - Inclusion in PubMed, CAS, Scopus and Google Scholar \\ - Research which is freely available for redistribution \\ Submit your manuscript at www.biomedcentral.com/submit}

C Biomed Central

(C) 2012 van Dam et al; licensee BioMed Central Ltd. This is an Open Access article distributed under the terms of the Creative Commons Attribution License (http://creativecommons.org/licenses/by/2.0), which permits unrestricted use, distribution, and reproduction in any medium, provided the original work is properly cited. 